\title{
Anticipated series average monthly price of gold in using the time series of software minitab
}

\author{
Shaban Mohammadi ${ }^{1 *}$, Mohammad Khademi \\ ${ }^{1}$ Department of Accounting, Quchan Branch,Hakim Nezami University, Quchan, Iran \\ 2 Department of Accounting, Quchan Branch,Hakim Nezami University, Quchan, Iran \\ *Corresponding author E-mail: shaban1362@gmail.com
}

\begin{abstract}
We can study the statistics, basic research to get the needs arising in different fields got considered. after knowing the statistics obtained from the trust issue is investigated, which is considered to be important. procedures because it is true that the correct result is achieved. and concluded with a detailed study on the mode of research is to identify the needs of current and non-current sources can be required by a suitable method found. the problem considered in this study in relation to the expected range of average monthly price of gold on the London market in terms of dollars. we are gathered here with the predicted theoretical and practical knowledge to study, and time series methods described above.
\end{abstract}

Keywords: Forecasting; Time Series; Trend Fitting; Always Making.

\section{Introduction}

The future of those who plan appropriately for it. merchants, institution or organization should be given to successful planning necessary to predict the future position to do it. there are several ways to do this. these methods can turn the past experience to predict future events. statistics relating to a variable that is expected to be available in the last period time series statistics say so. the purpose of a time series, a collection of statistical data that are collected at regular intervals equal. these data and the statistical methods used to analyze the time series is called. forecasting is an importan element in management decisions, because any decision on the nature of the final performance of a sequence of events that occur subsequent decision. because management systems for planning and controlling the operations of an organization typically enjoy a forecast function. because the predicted never quite does not eliminate a risk. it is necessary that the decision-making process immediately following the forecast uncertainty is left to consider (Frankfurter et al. 1996). to measure the accuracy of the model was fitted to a series of three criteria, namely MAPE, MSD, MAD is used to measure them carefully or call measures of accuracy.

\section{Anticipated series of the average monthly price of gold:}

Monthly data relating to the supply price of one ounce of gold in dollar terms during the London Metal Market 1968 - 2007 AD, the site has been kitco.com as follows.

\begin{tabular}{|c|c|c|c|c|c|c|c|}
\hline Row & year & month & gold & Row & year & month & gold \\
\hline 1 & 1968 & Jan & 35.20 & 241 & 1988 & Jan & 476.58 \\
\hline 2 & 1968 & Feb & 35.20 & 242 & 1988 & Feb & 442.07 \\
\hline 3 & 1968 & Mar & 35.20 & 243 & 1988 & Mar & 443.61 \\
\hline 4 & 1968 & Apr & 37.90 & 244 & 1988 & Apr & 451.55 \\
\hline 5 & 1968 & May & 40.70 & 245 & 1988 & May & 451.01 \\
\hline 6 & 1968 & Jun & 41.10 & 246 & 1988 & Jun & 451.33 \\
\hline 7 & 1968 & Jul & 39.50 & 247 & 1988 & Jul & 437.63 \\
\hline 8 & 1968 & Aug & 39.20 & 248 & 1988 & Aug & 431.31 \\
\hline 9 & 1968 & Sep & 40.20 & 249 & 1988 & Sep & 412.79 \\
\hline 10 & 1968 & Oct & 39.20 & 250 & 1988 & Oct & 406.78 \\
\hline 13 & 1969 & Jan & 42.30 & 253 & 1989 & Jan & 404.01 \\
\hline 14 & 1969 & Feb & 42.60 & 254 & 1989 & Feb & 387.78 \\
\hline 15 & 1969 & Mar & 43.20 & 255 & 1989 & Mar & 390.15 \\
\hline 16 & 1969 & Apr & 43.30 & 256 & 1989 & Apr & 384.06 \\
\hline 17 & 1969 & May & 43.46 & 257 & 1989 & May & 371.00 \\
\hline 18 & 1969 & Jun & 41.44 & 258 & 1989 & Jun & 367.60 \\
\hline 19 & 1969 & Jul & 41.76 & 259 & 1989 & Jul & 375.04 \\
\hline 20 & 1969 & Aug & 41.09 & 260 & 1989 & Aug & 365,037 \\
\hline 21 & 1969 & Sep & 40.87 & 261 & 1989 & Sep & 361.75 \\
\hline 22 & 1969 & Oct & 40.44 & 262 & 1989 & Oct & 366.88 \\
\hline 23 & 1969 & Nov & 37.40 & 263 & 1989 & Nov & 394.26 \\
\hline 24 & 1969 & Dec & 35.17 & 264 & 1989 & Dec & 409.39 \\
\hline 25 & 1970 & Jan & 34.94 & 265 & 1989 & Jan & 410.11 \\
\hline 26 & 1970 & Feb & 34.99 & 266 & 1990 & Feb & 416.83 \\
\hline 27 & 1970 & Mar & 35.09 & 267 & 1990 & Mar & 393.07 \\
\hline 28 & 1970 & Apr & 35.62 & 268 & 1990 & Apr & 374.27 \\
\hline 29 & 1970 & May & 35.95 & 269 & 1990 & May & 369.19 \\
\hline 30 & 1970 & Jun & 35.44 & 270 & 1990 & Jun & 352.33 \\
\hline 31 & 1970 & Jul & 35.32 & 271 & 1990 & Jul & 362.53 \\
\hline 32 & 1970 & Aug & 35.38 & 272 & 1990 & Aug & 394.73 \\
\hline 33 & 1970 & Sep & 36.19 & 273 & 1990 & Sep & 388.41 \\
\hline 34 & 1970 & Oct & 37.52 & 274 & 1990 & Oct & 380.74 \\
\hline 35 & 1970 & Nov & 37.44 & 275 & 1990 & Nov & 381.73 \\
\hline 36 & 1970 & Dec & 37.44 & 276 & 1990 & Dec & 378.16 \\
\hline 37 & 1971 & Jan & 37.87 & 277 & 1991 & Jan & 383.64 \\
\hline 38 & 1971 & Feb & 38.74 & 278 & 1991 & Feb & 363.83 \\
\hline 39 & 1971 & Mar & 38.87 & 279 & 1991 & Mar & 363.33 \\
\hline
\end{tabular}

Copyright () 2015 Shaban Mohammadi. This is an open access article distributed under the Creative Commons Attribution License, which permits unrestricted use, distribution, and reproduction in any medium, provided the original work is properly cited. 


\begin{tabular}{llllllll}
\hline 40 & 1971 & Apr & 39.01 & 280 & 1991 & Apr & 358.39 \\
41 & 1971 & May & 40.52 & 281 & 1991 & May & 356.82 \\
42 & 1971 & Jun & 40.10 & 282 & 1991 & Jun & 366.72 \\
43 & 1971 & Jul & 40.95 & 283 & 1991 & Jul & 367.68 \\
44 & 1971 & Aug & 42.73 & 284 & 1991 & Aug & 356.23 \\
45 & 1971 & Sep & 42.02 & 285 & 1991 & Sep & 348.74 \\
46 & 1971 & Oct & 42.50 & 286 & 1991 & Oct & 358.69 \\
47 & 1971 & Nov & 42.86 & 287 & 1991 & Nov & 360.17 \\
48 & 1971 & Dec & 43.48 & 288 & 1991 & Dec & 361.06 \\
49 & 1972 & Jan & 45.75 & 289 & 1992 & Jan & 354.45 \\
50 & 1972 & Feb & 48.26 & 290 & 1992 & Feb & 353.89 \\
51 & 1972 & Mar & 48.33 & 291 & 1992 & Mar & 344.35 \\
52 & 1972 & Apr & 49.03 & 292 & 1992 & Apr & 338.50 \\
53 & 1972 & May & 54.62 & 293 & 1992 & May & 337.23 \\
54 & 1972 & Jun & 62.09 & 294 & 1992 & Jun & 340.80 \\
55 & 1972 & Jul & 65.67 & 295 & 1992 & Jul & 353.05 \\
\hline
\end{tabular}

\begin{tabular}{|c|c|c|c|c|c|c|c|}
\hline 119 & 1977 & Nov & 162.10 & 359 & 1997 & Nov & 306.04 \\
\hline 120 & 1977 & Dec & 160.45 & 360 & 1997 & Dec & 288.74 \\
\hline 121 & 1977 & Jan & 173.17 & 361 & 1998 & Jan & 289.15 \\
\hline 122 & 1978 & Feb & 178.15 & 362 & 1998 & Feb & 297.49 \\
\hline 123 & 1978 & Mar & 183.66 & 363 & 1998 & Mar & 295.94 \\
\hline 124 & 1978 & Apr & 175.27 & 364 & 1998 & Apr & 308.29 \\
\hline 125 & 1978 & May & 176.30 & 365 & 1998 & May & 299.10 \\
\hline 126 & 1978 & Jun & 183.75 & 366 & 1998 & Jun & 292.32 \\
\hline 127 & 1978 & Jul & 188.72 & 367 & 1998 & Jul & 292.87 \\
\hline 128 & 1978 & Aug & 206.30 & 368 & 1998 & Aug & 284.11 \\
\hline 129 & 1978 & Sep & 212.07 & 369 & 1998 & Sep & 288.98 \\
\hline 130 & 1978 & Oct & 227.39 & 370 & 1998 & Oct & 296.22 \\
\hline 131 & 1978 & Nov & 206.07 & 371 & 1998 & Nov & 294.77 \\
\hline 132 & 1978 & Dec & 207.83 & 372 & 1998 & Dec & 291.62 \\
\hline 133 & 1979 & Jan & 227.27 & 373 & 1999 & Jan & 987.07 \\
\hline 134 & 1979 & Feb & 243.67 & 374 & 1999 & Feb & 287.22 \\
\hline 135 & 1979 & Mar & 242.04 & 375 & 1999 & Mar & 289.96 \\
\hline 136 & 1979 & Apr & 239.16 & 376 & 1999 & Apr & 282.62 \\
\hline 137 & 1979 & May & 257.61 & 377 & 1999 & May & 276.88 \\
\hline 138 & 1979 & Jun & 279.06 & 378 & 1999 & Jun & 261.37 \\
\hline 139 & 1979 & Jul & 294.73 & 379 & 1999 & Jul & 256.08 \\
\hline 140 & 1979 & Aug & 300.81 & 380 & 1999 & Aug & 256.70 \\
\hline 141 & 1979 & Sep & 355.11 & 381 & 1999 & Sep & 266.60 \\
\hline 142 & 1979 & Oct & 391.65 & 382 & 1999 & Oct & 310.72 \\
\hline 143 & 1979 & Nov & 391.99 & 383 & 1999 & Nov & 293.01 \\
\hline 144 & 1979 & Dec & 455.08 & 384 & 1999 & Dec & 282.37 \\
\hline 145 & 1980 & Jan & 675.30 & 385 & 2000 & Jan & 284.32 \\
\hline 146 & 1980 & Feb & 655.32 & 386 & 2000 & Feb & 299.94 \\
\hline 147 & 1980 & Mar & 553.58 & 387 & 2000 & Mar & 286.39 \\
\hline 148 & 1980 & Apr & 517.41 & 388 & 2000 & Apr & 279.86 \\
\hline 149 & 1980 & May & 513.82 & 389 & 2000 & May & 275.31 \\
\hline 150 & 1980 & Jun & 600.71 & 390 & 2000 & Jun & 285.73 \\
\hline 151 & 1980 & Jul & 644.28 & 391 & 2000 & Jul & 281.55 \\
\hline 152 & 1980 & Aug & 627.14 & 392 & 2000 & Aug & 274.47 \\
\hline 153 & 1980 & Sep & 673.62 & 393 & 2000 & Sep & 273.68 \\
\hline 154 & 1980 & Oct & 661.14 & 394 & 2000 & Oct & 270.00 \\
\hline 155 & 1980 & Nov & 623.46 & 395 & 2000 & Nov & 266.01 \\
\hline 156 & 1980 & Dec & 594.92 & 396 & 2000 & Dec & 271.45 \\
\hline 157 & 1981 & Jan & 557.38 & 397 & 2001 & Jan & 265.49 \\
\hline 158 & 1981 & Feb & 499.76 & 398 & 2001 & Feb & 261.86 \\
\hline 159 & 1981 & Mar & 498.76 & 399 & 2001 & Mar & 263.03 \\
\hline 160 & 1981 & Apr & 495.80 & 400 & 2001 & Apr & 260.48 \\
\hline 161 & 1981 & May & 479.69 & 401 & 2001 & May & 272.35 \\
\hline 162 & 1981 & Jun & 464.76 & 402 & 2001 & Jun & 270.23 \\
\hline 163 & 1981 & Jul & 409.28 & 403 & 2001 & Jul & 267.53 \\
\hline 164 & 1981 & Aug & 410.15 & 404 & 2001 & Aug & 272.39 \\
\hline 165 & 1981 & Sep & 443.58 & 405 & 2001 & Sep & 283.42 \\
\hline 166 & 1981 & Oct & 437.75 & 406 & 2001 & Oct & 283.06 \\
\hline 167 & 1981 & Nov & 413.36 & 407 & 2001 & Nov & 276.15 \\
\hline 168 & 1981 & Dec & 410.09 & 408 & 2002 & Dec & 275.85 \\
\hline 169 & 1982 & Jan & 384.38 & 409 & 2002 & Jan & 281.65 \\
\hline 170 & 1982 & Feb & 374.13 & 410 & 2002 & Feb & 295.50 \\
\hline 171 & 1982 & Mar & 330.04 & 411 & 2002 & Mar & 294.05 \\
\hline 172 & 1982 & Apr & 350.35 & 412 & 2002 & Apr & 302.64 \\
\hline 173 & 1982 & May & 333.82 & 413 & 2002 & May & 314.49 \\
\hline 174 & 1982 & Jun & 314.98 & 414 & 2002 & Jun & 321.18 \\
\hline 175 & 1982 & Jul & 338.97 & 415 & 2002 & Jul & 313.29 \\
\hline 176 & 1982 & Aug & 364.23 & 416 & 2002 & Aug & 310.25 \\
\hline 177 & 1982 & Sep & 435.76 & 417 & 2002 & Sep & 319.16 \\
\hline 178 & 1982 & Oct & 422.15 & 418 & 2002 & Oct & 316.56 \\
\hline 179 & 1982 & Nov & 414.91 & 419 & 2002 & Nov & 319.15 \\
\hline 180 & 1982 & Dec & 444.30 & 420 & 2002 & Dec & 332.43 \\
\hline 181 & 1983 & Jan & 481,29 & 421 & 2003 & Jan & 356.86 \\
\hline 182 & 1983 & Feb & 491.96 & 422 & 2003 & Feb & 354.97 \\
\hline 183 & 1983 & Mar & 419.70 & 423 & 2003 & Mar & 340.55 \\
\hline 184 & 1983 & Apr & 432.93 & 424 & 2003 & Apr & 328.18 \\
\hline 185 & 1983 & May & 438.08 & 425 & 2003 & May & 355.68 \\
\hline 186 & 1983 & Jun & 412.84 & 426 & 2003 & Jun & 356.53 \\
\hline 187 & 1983 & Jul & 422.72 & 427 & 2003 & Jul & 351.02 \\
\hline 188 & 1983 & Aug & 416.24 & 428 & 2003 & Aug & 359.77 \\
\hline 189 & 1983 & Sep & 412.80 & 429 & 2003 & Sep & 378.95 \\
\hline 190 & 1983 & Oct & 339.58 & 430 & 2003 & Oct & 378.92 \\
\hline 191 & 1983 & Nov & 381.66 & 431 & 2003 & Nov & 389.91 \\
\hline 192 & 1983 & Dec & 389.36 & 432 & 2003 & Dec & 407.59 \\
\hline 193 & 1984 & Jan & 370.90 & 433 & 2004 & Jan & 413.99 \\
\hline 194 & 1984 & Feb & 386.33 & 434 & 2004 & Feb & 405.33 \\
\hline 195 & 1984 & Mar & 394.33 & 435 & 2004 & Mar & 406.67 \\
\hline 196 & 1984 & Apr & 381.36 & 436 & 2004 & Apr & 403.20 \\
\hline 197 & 1984 & May & 377.40 & 437 & 2004 & May & 383.45 \\
\hline 198 & 1984 & Jun & 377.67 & 438 & 2004 & Jun & 391.99 \\
\hline
\end{tabular}




\begin{tabular}{|c|c|c|c|c|c|c|c|}
\hline 199 & 1984 & Jul & 347.45 & 439 & 2004 & Jul & 398.09 \\
\hline 200 & 1984 & Aug & 347.70 & 440 & 2004 & Aug & 400.48 \\
\hline 201 & 1984 & Sep & 341.09 & 441 & 2004 & Sep & 405.27 \\
\hline 202 & 1984 & Oct & 340.17 & 442 & 2004 & Oct & 420.46 \\
\hline 203 & 1984 & Nov & 341.19 & 443 & 2004 & Nov & 439.39 \\
\hline 204 & 1984 & Dec & 320.14 & 444 & 2004 & Dec & 441.76 \\
\hline 205 & 1985 & Jan & 302.74 & 445 & 2005 & Jan & 424.15 \\
\hline 206 & 1985 & Feb & 299.10 & 446 & 2005 & Feb & 423.35 \\
\hline 207 & 1985 & Mar & 304.17 & 447 & 2005 & Mar & 434.24 \\
\hline 208 & 1985 & Apr & 324.74 & 448 & 2005 & Apr & 428.93 \\
\hline 209 & 1985 & May & 316.64 & 449 & 2005 & May & 421.87 \\
\hline 210 & 1985 & Jun & 316.83 & 450 & 2005 & Jun & 430.66 \\
\hline 211 & 1985 & Jul & 317.38 & 451 & 2005 & Jul & 424.48 \\
\hline 212 & 1985 & Aug & 329.33 & 452 & 2005 & Aug & 437.93 \\
\hline 213 & 1985 & Sep & 324.25 & 453 & 2005 & Sep & 456.04 \\
\hline 214 & 1985 & Oct & 325.93 & 454 & 2005 & Oct & 469.90 \\
\hline 215 & 1985 & Nov & 352.22 & 455 & 2005 & Nov & 476.67 \\
\hline 216 & 1985 & Dec & 320.81 & 456 & 2005 & Dec & 509.76 \\
\hline 217 & 1986 & Jan & 345.38 & 457 & 2006 & Jan & 549.86 \\
\hline 218 & 1986 & Feb & 338.89 & 458 & 2006 & Feb & 555.00 \\
\hline 219 & 1986 & Mar & 345.71 & 459 & 2006 & Mar & 557.09 \\
\hline 220 & 1986 & Apr & 340.44 & 460 & 2006 & Apr & 610.65 \\
\hline 221 & 1986 & May & 342.56 & 461 & 2006 & May & 676.51 \\
\hline 222 & 1986 & Jun & 342.57 & 462 & 2006 & Jun & 596.15 \\
\hline 223 & 1986 & Jul & 348.54 & 463 & 2006 & Jul & 633.77 \\
\hline 224 & 1986 & Aug & 376.60 & 464 & 2006 & Aug & 632.59 \\
\hline 225 & 1986 & Sep & 317.73 & 465 & 2006 & Sep & 598.19 \\
\hline 226 & 1986 & Oct & 423.51 & 466 & 2006 & Oct & 585.78 \\
\hline 227 & 1986 & Nov & 398.81 & 467 & 2006 & Nov & 627.83 \\
\hline 228 & 1986 & Dec & 391.23 & 468 & 2006 & Dec & 629.79 \\
\hline 229 & 1987 & Jan & 408.26 & 469 & 2007 & Jan & 631.71 \\
\hline 230 & 1987 & Feb & 401.12 & 470 & 2007 & Feb & 664.75 \\
\hline 231 & 1987 & Mar & 408.91 & 471 & 2007 & Mar & 654.90 \\
\hline 232 & 1987 & Apr & 438.35 & 472 & 2007 & Apr & 679.37 \\
\hline 233 & 1987 & May & 460.23 & 473 & 2007 & May & 666.86 \\
\hline 234 & 1987 & Jun & 449.59 & 474 & 2007 & Jun & 655.49 \\
\hline 235 & 1987 & Jul & 450.52 & 475 & 2007 & Jul & 665.30 \\
\hline 236 & 1987 & Aug & 461.15 & 476 & 2007 & Aug & 665.41 \\
\hline 237 & 1987 & Sep & 460.20 & 477 & 2007 & Sep & 712.65 \\
\hline 238 & 1987 & Oct & 465.36 & 478 & 2007 & Oct & 754.60 \\
\hline 239 & 1987 & Nov & 467.57 & 479 & 2007 & Nov & 806.25 \\
\hline 240 & 1987 & Dec & 486.31 & 480 & 2007 & Dec & 803.20 \\
\hline
\end{tabular}

To recognize changes in time series graph for this data series are plotted. chart data series to be as follows.

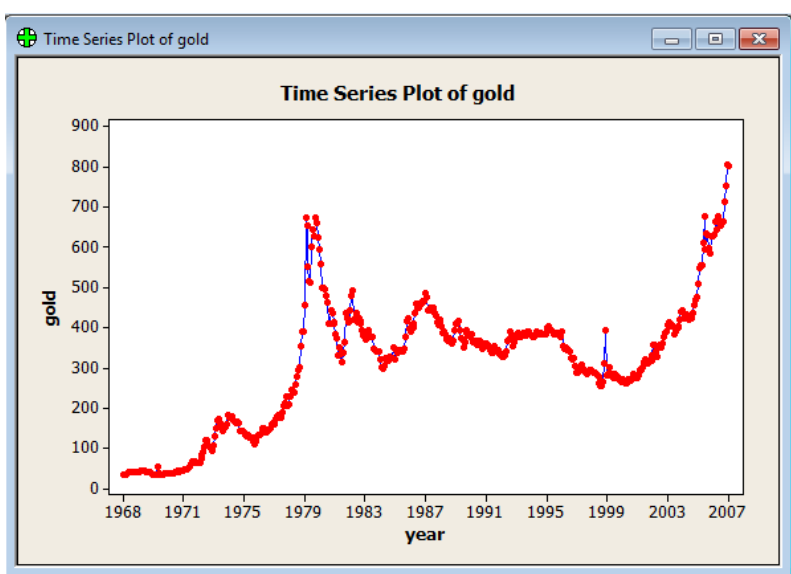

Monthly time series chart of gold price from 1968 to 2007.

preliminary results can be seen in the following diagram realized the diagram shows that during 1968 and 1972, significant changes occurred in the gold price. during 1973 to 1975, we see the growth of a few tens of dollars. during the years 1976 to 1981, we see the growth of a few hundred dollars. It seems that in both 1982 and 1983, about three hundred dollars suddenly confronted with negative growth and decline. during 1984 the growth and decline during 1987 and 1993, the increase from 1993 to 1996 and 1996 to 2002, faced with declining gold prices. however, between 2002 and 2007 AD by the unprecedented growth of more than 1980 to 1996 have been met. there are certain trends in the data, we are trying to investigate. therefore, the linear model (linear) degree (quadratic) exponential (exponential growth) to fit our data. we have the following three forms. ( Jose et al. 1996).

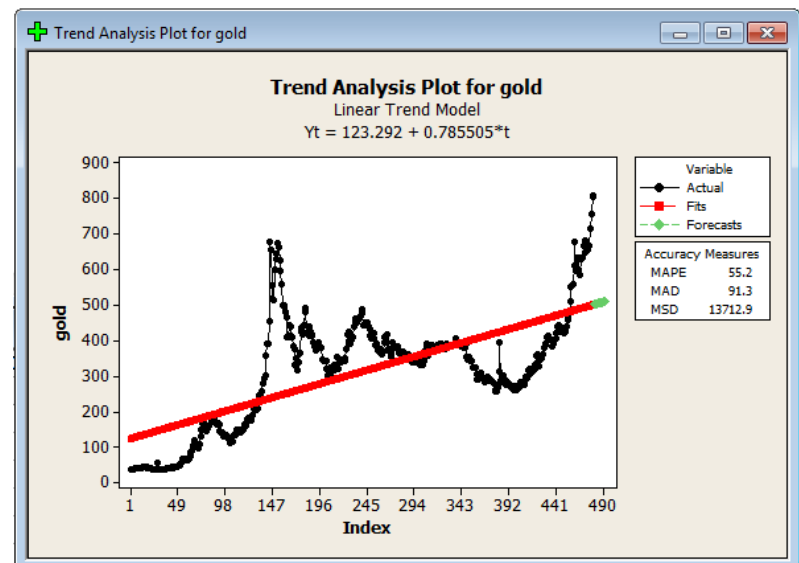

linear process model diagram for the monthly price of gold.

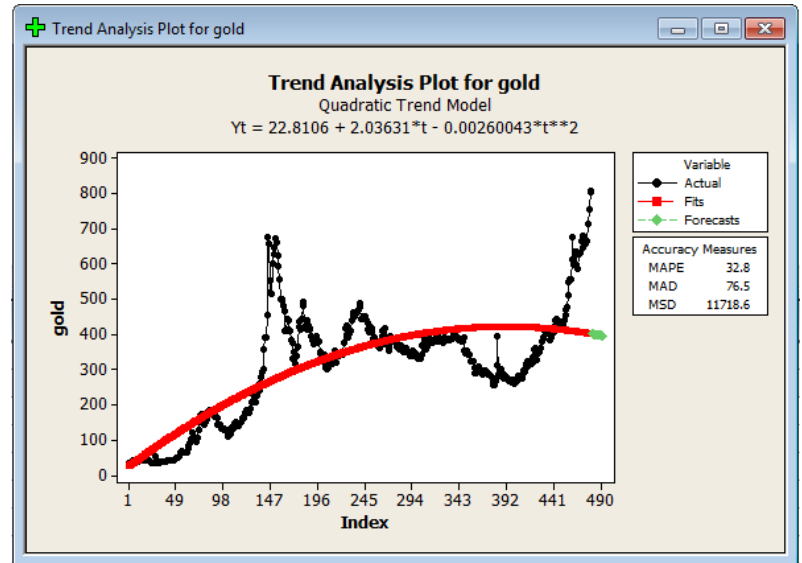

Graph the quadratic model for the monthly price of gold.

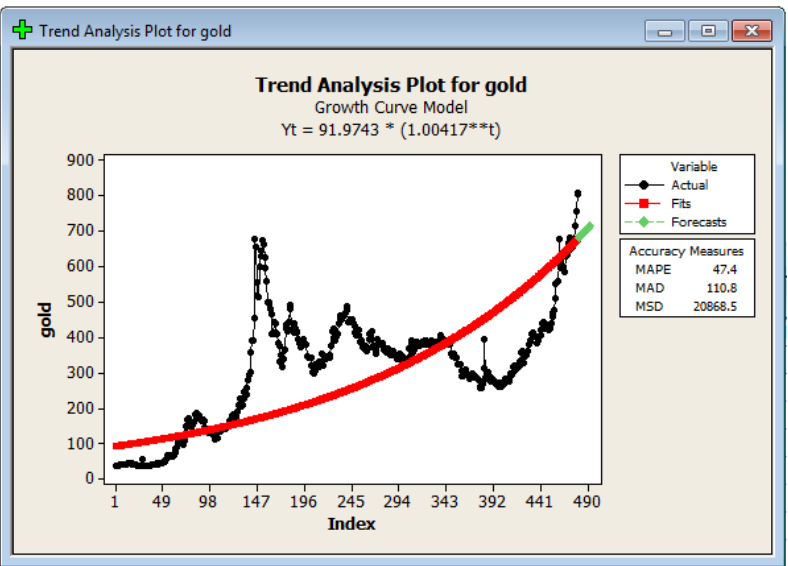

Trend analysis plot for gold.

view the data model diagram for a monthly price of gold.in the table below we compare the standards of accuracy.

\begin{tabular}{ll|ll}
\hline & MAPE & MAD & MSD \\
\hline Linear & 55.2 & 91.3 & 13712.9 \\
Quadratic & 32.8 & 76.5 & 11718.6 \\
Exponential growth & 47.4 & 110.8 & 20868.5 \\
\hline
\end{tabular}

According to the results of the standards and precision fitted trend lines, it can be seen that the quadratic model fit the data better Is. therefore, this model is as follows. 


\section{$y_{c}=22.8106+2.03631 * t-0.00260043 * t * * 2$}

Using the model predictions for the next twelve months will be as follows:

$\begin{array}{lr}\text { Forecasts } \\ \text { Period } & \text { Forecast } \\ 481 & 400.638 \\ 482 & 400.171 \\ 483 & 399.697 \\ 484 & 399.219 \\ 485 & 398.736 \\ 486 & 398.247 \\ 487 & 397.753 \\ 488 & 397.254 \\ 489 & 396.750 \\ 490 & 396.240 \\ 491 & 395.725 \\ 492 & 395.205\end{array}$

To better understand the seasonal changes of charts we use data analysis.

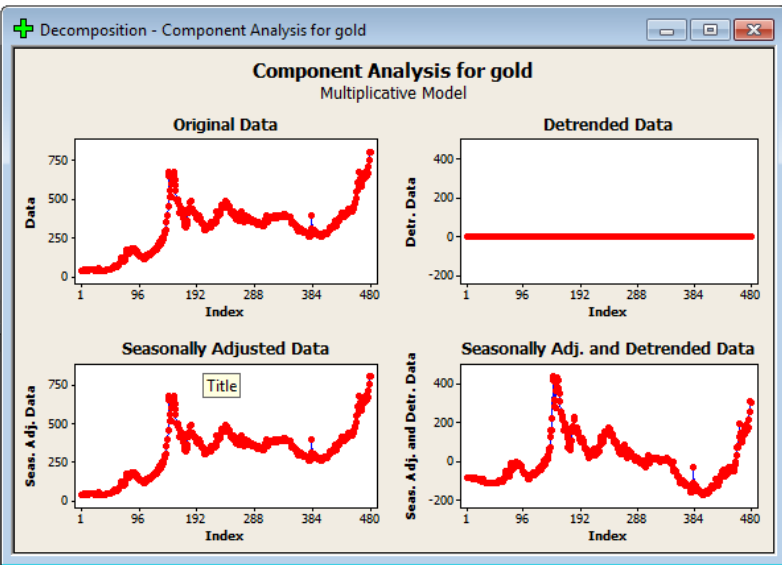

Component analysis for gold

due to the difference between detrended data to create charts and graphs original data in the data, but we because there is no difference between the original data and seasonally adjusted data we infer that the data has seasonal variations are not. using four methods to predict the next twelve months we have.( Yue et al. 2007)

\section{Always the moving average method}

Detailed submission guidelines can be found on the journal web pages. all authors are responsible for understanding these guidelines before submitting their manuscript.

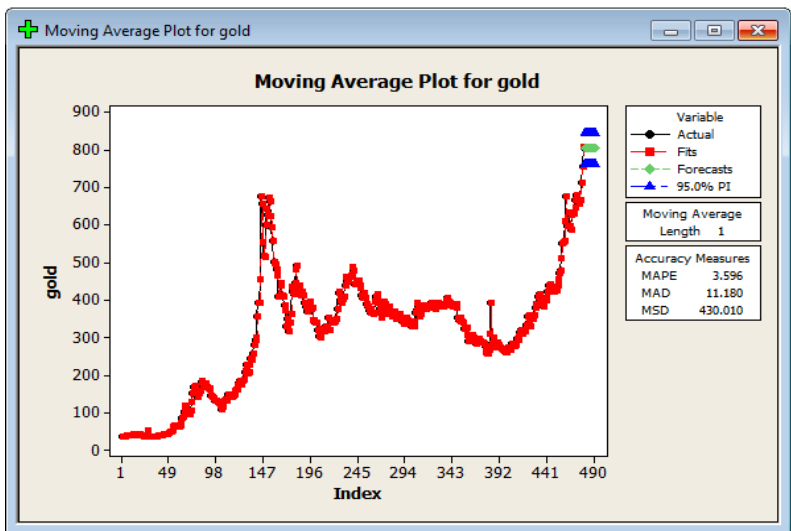

Moving Average monthly gold price chart for data.

\section{Method always making view only}

One way is always and only looks like the models and linear fit to the data, we can according to precise criteria and the diagram is a good way to check whether or not anticipated.

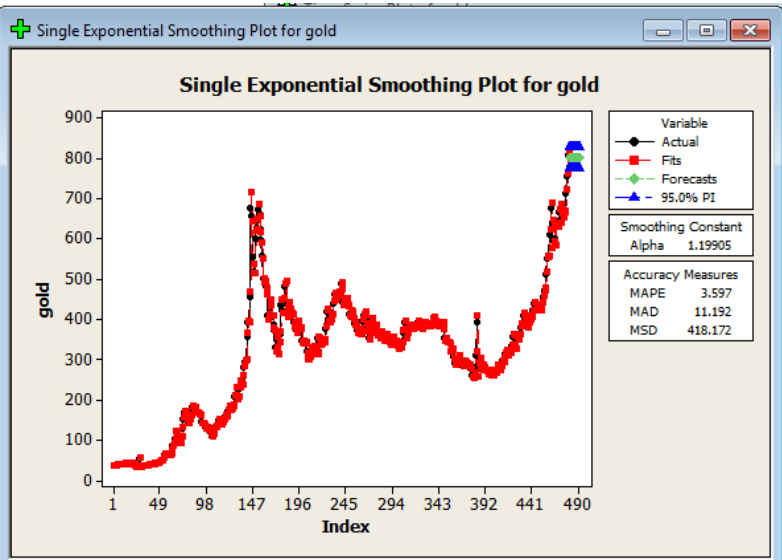

Single exponential smoothing data monthly price chart for gold

\section{The method has the double exponential the data are plotted below.}

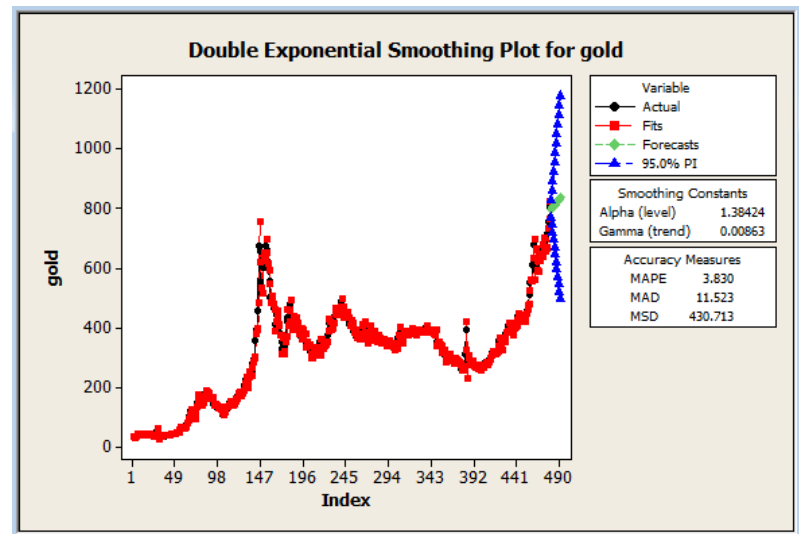

Double exponential smoothing data monthly price chart for gold

\section{Winters smoothing data method is as fol- lows}

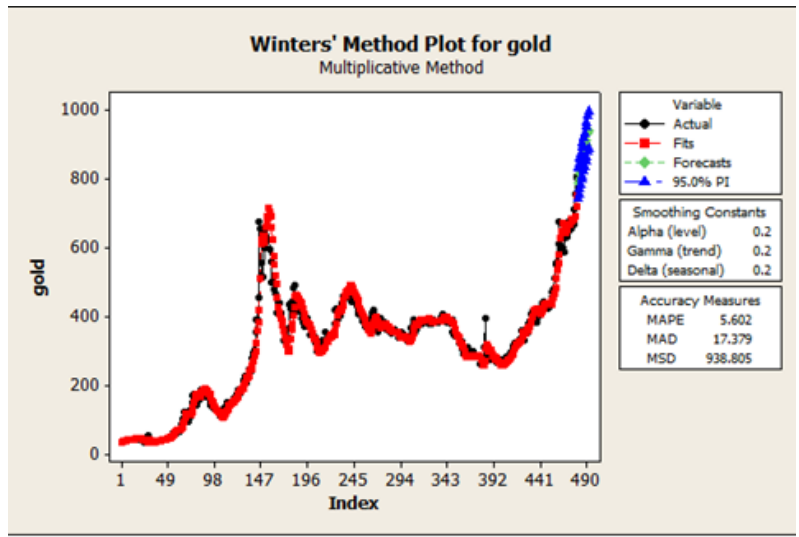

Winters smoothing data monthly price chart for gold.

Below are benchmarks to compare the accuracy of the four methods described above. 


\begin{tabular}{llll}
\hline & MAPE & MAD & MSD \\
\hline Single & 3.597 & 11.192 & 418.172 \\
Double & 3.830 & 11.523 & 430.713 \\
Winters & 5.602 & 17.397 & 938.805 \\
\hline
\end{tabular}

This indicates that the method gives a better fit to the data is unique. the predicted values for the following twelve months.

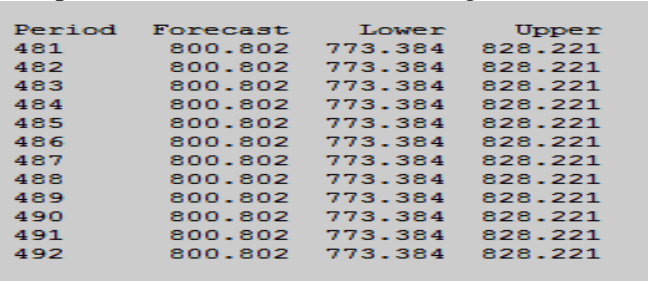

\section{Diagnostic test model (ARIMA)}

As the plot of this series is the series at an average is specified. ACF sample survey also confirms the non-stationary series. as you can see the values of the autocorrelation function are very slow to zero.

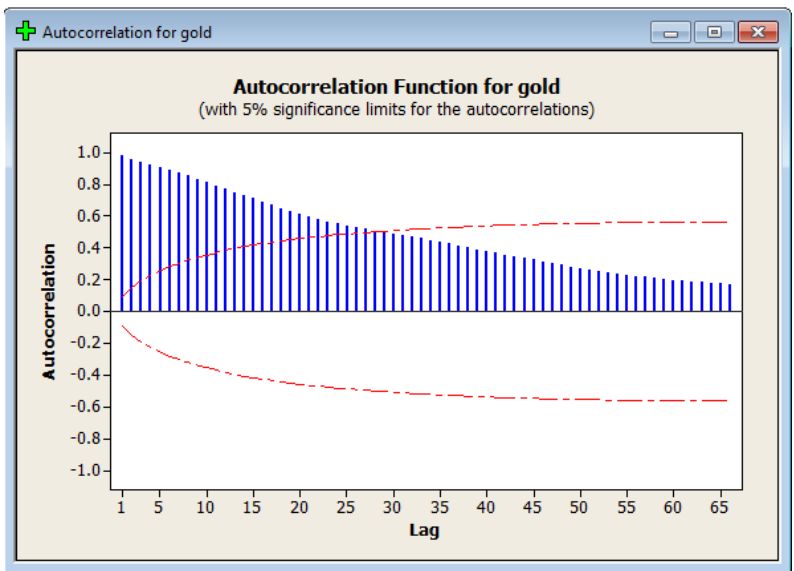

Autocorrelation function for gold.

however, with the implementation of the Box-Cox procedure to examine the stability of the variance.

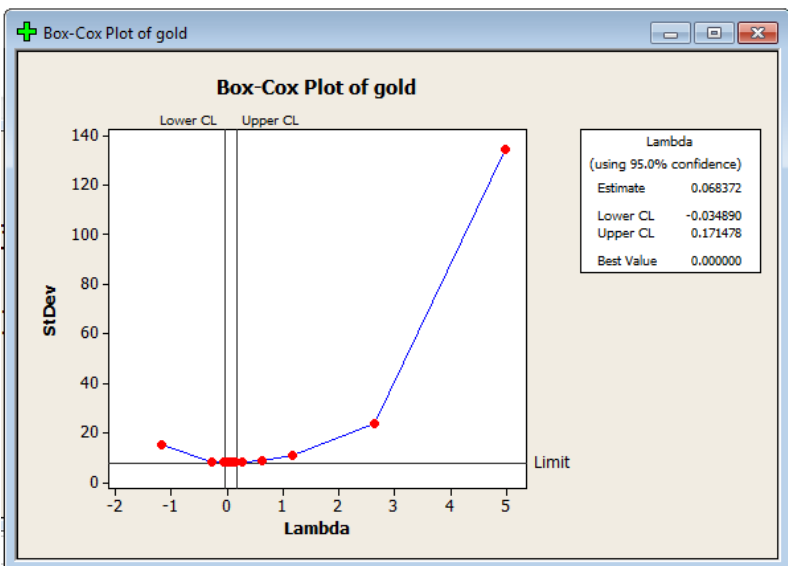

Cox Baks- chart data monthly price for gold.

As number one in the band is not so stable variance to the BoxCox transformation of the stationary variance was 7.1. after the

conversion, for $\lambda=1) \ln \left(x_{z}\right)$ we use to do this conversion does not work.

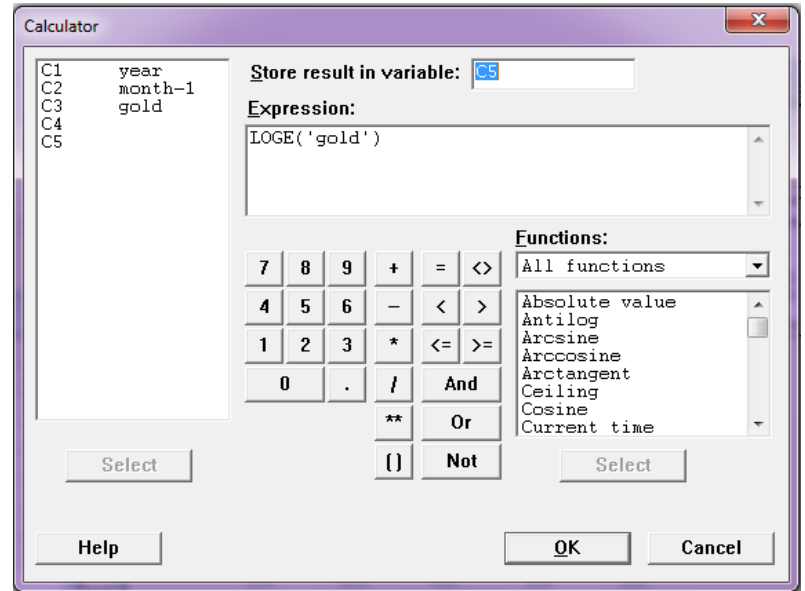

Store results in variable: new data from the conversion are included in this column. expression: change we want to write mathematically by the following box. then click on ok to do the necessary conversions and new data are entered in column C5. Box-Cox plots to ensure the data is plotted to C5.

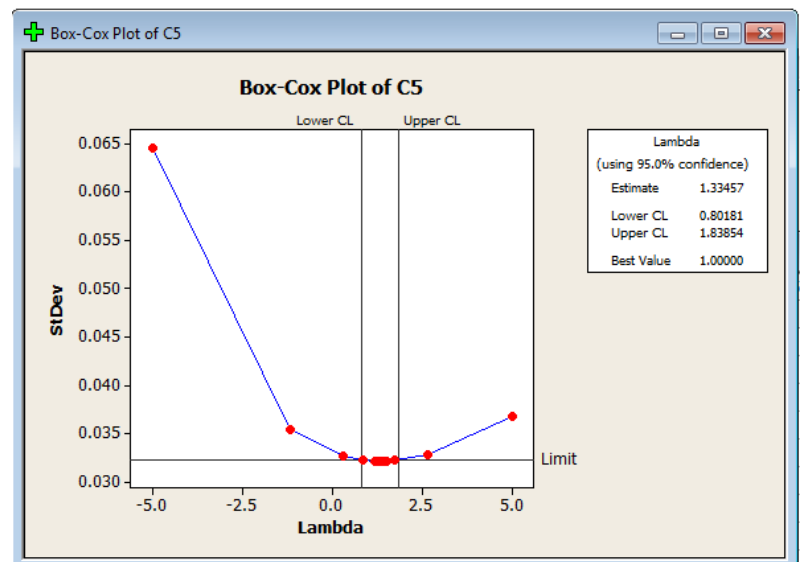

Box-cox plot for gold monthly price data after conversion (after stabilization of variance).

as can be seen, the number one in the band is sure to become the choice is indicated. to solve the problem of non-stationary, the differential time series are given. differential series with $\mathrm{C} 4$ show. However, time series graphs are plotted for a series of difference.

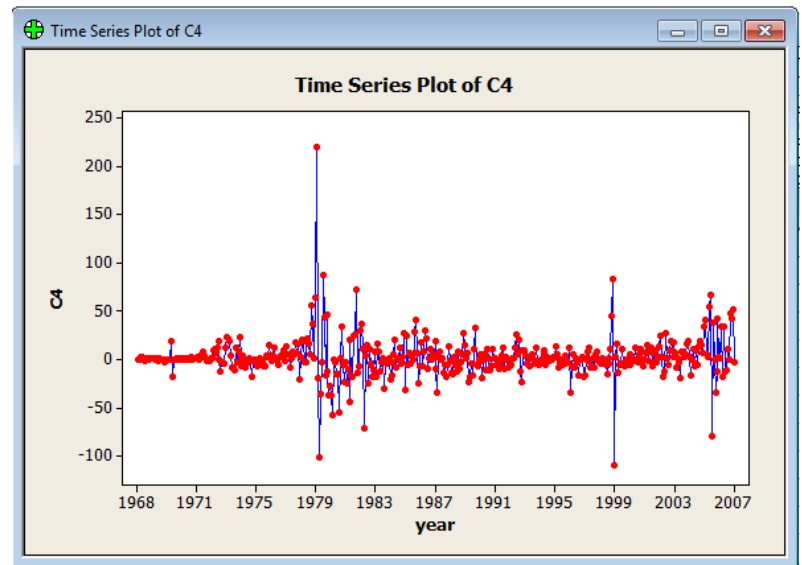

Time-series data monthly price chart for gold after stabilize the variance and differential.

as you can see, the series is the result of a series of stationary time series ARIMA models fitted to a suitable model of these families did. 


\section{Sample PACF, ACF}

To plot the differential series of PACF, ACF important tool in determining the autocorrelation function, partial autocorrelation function is. draw a diagram of the process is helpful in determining the type and level. to identify the best model is recommended that a sample size of at least 50 APCF, ACF delayed at least $\mathrm{K}=\mathrm{n}$ / 4 are calculated and graphed.

\begin{tabular}{lll}
\hline & ACF & PACF \\
\hline AR(P) & $\begin{array}{l}\text { As an exponential } \\
\text { decay to zero or a sine } \\
\text { wave }\end{array}$ & $\begin{array}{l}\text { After a delay of p is disconnect- } \\
\text { ed }\end{array}$ \\
Q will be cut off after & $\begin{array}{l}\text { As an exponential decay to zero } \\
\text { a delay a sine wave } \\
\text { After the delay (qp) to } \\
\text { zero }\end{array}$ & $\begin{array}{l}\text { After the delay (pq) to zero } \\
\text { ARMA(p,q) }\end{array}$ \\
\hline
\end{tabular}

\section{Autocorrelation plot of static data ACF}

an experimental method for determining the degree of MA recognize that given the lags of the autocorrelation curve $q=2$ is observed. $($ lag $=1.8)$.

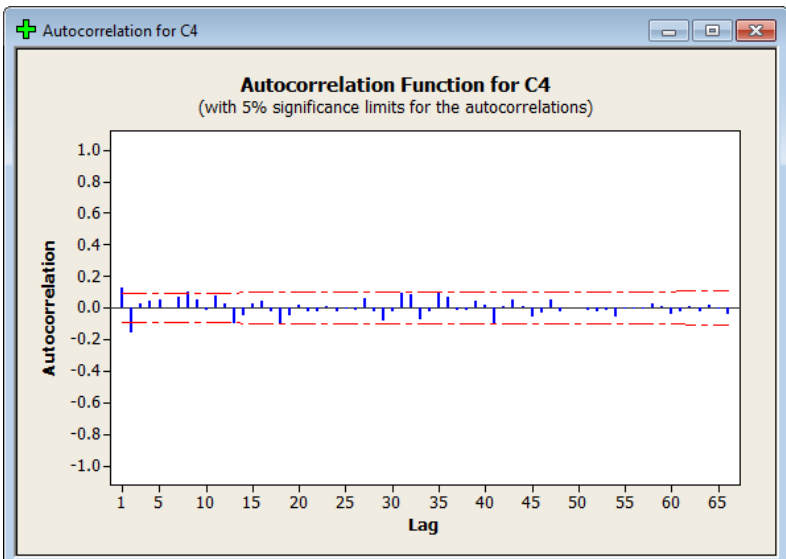

ACF chart data monthly price for gold after stabilize the variance and differential.

\section{Partial autocorrelation plot of the static data PACF}

An experimental method for determining the degree of AR diagnosis of the partial autocorrelation plot is due to lags $\mathrm{P}=2$ is observed. $($ Lag lag $=1.7)$

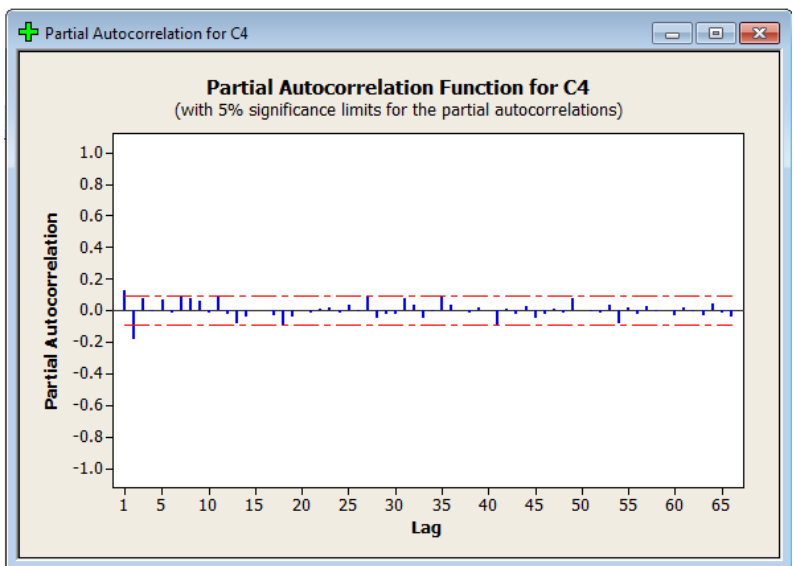

Pacf chart for gold after fixing the variance of monthly price data.

\section{There is a definite trend in the model test}

However, given the above steps and diagrams acf, pacf that goes to zero, the test model ARIMA assume and we argued about it properly.

\section{Investigation and analysis on the resid- uals}

If the ARIMA, model are diagnosed, then the residuals of the fit of the model to be approximately has the properties of a normal random variable with mean zero and variance are fixed independently distributed. if no model is appropriate to the remaining structure. this means that should any other variables such as command data collection or estimated values are irrelevant. any structure in these graphs showed the effect on the response variable is. one way to analyze charts of the remaining residues are examined. ARIMA for the main window by selecting the desired graphs can offer.

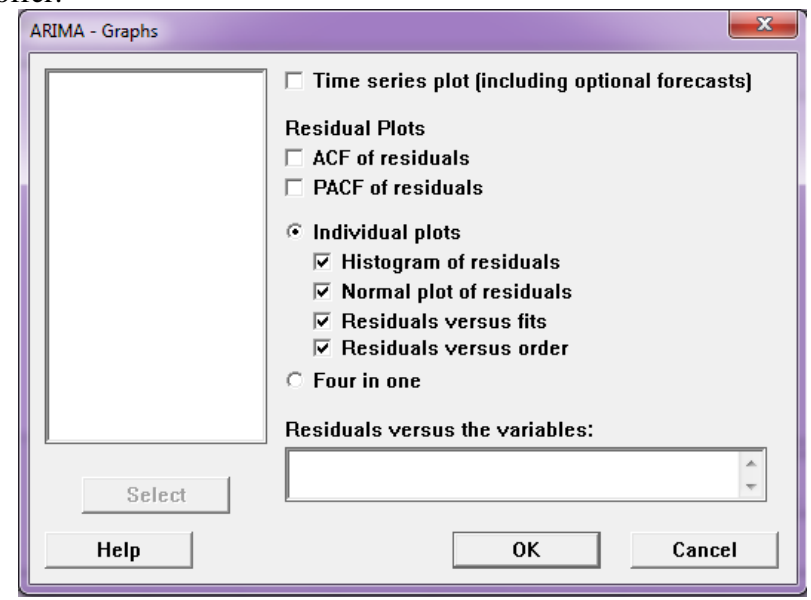

thus, under the assumption of normality of the residuals charts to confirm.

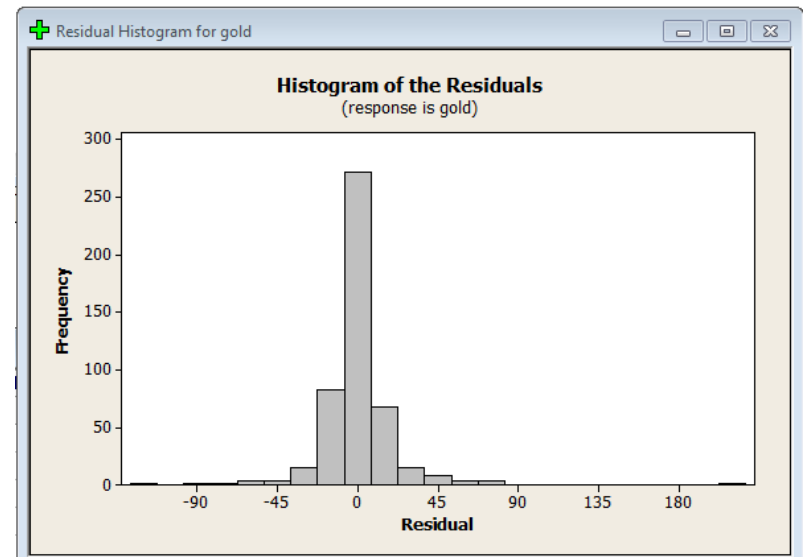

histograms of the residuals for the monthly price of gold. 


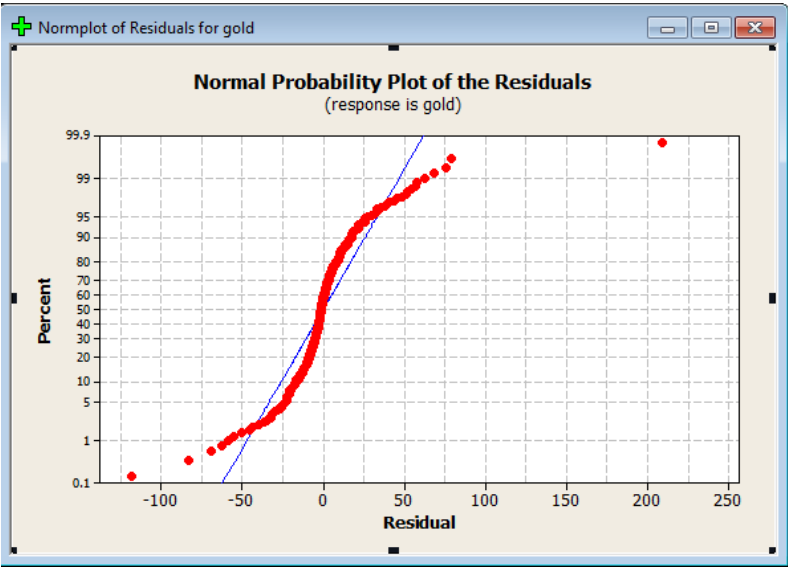

Linden possibility remained normal for the monthly price of gold. Graphs ACF, PACF below do not show specific plans and delays are not significantly different from zero. thus, assuming independence of residuals will be accepted.

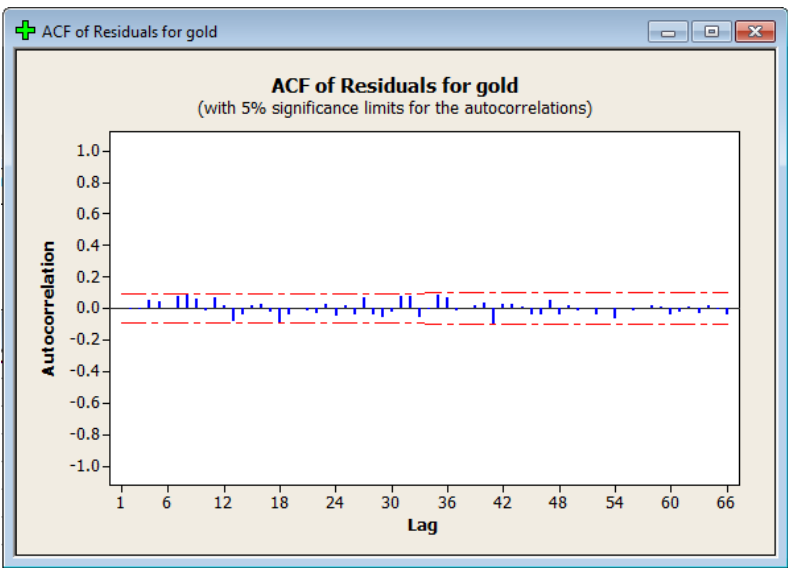

ACF remaining data monthly price chart for gold.

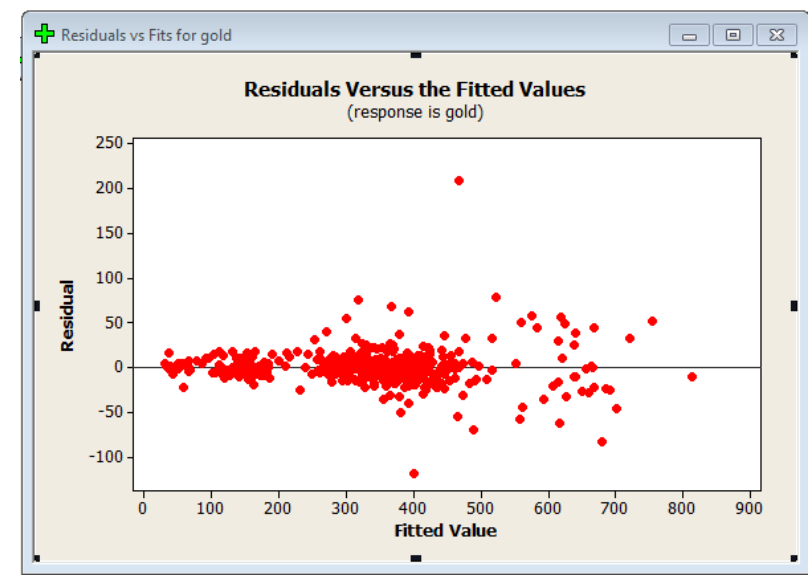

Residual versus the fitted values.

plot of residuals against fitted values for the monthly price of gold the remaining charts at the same time against accidental impacts resulting from the process are pure chaos.

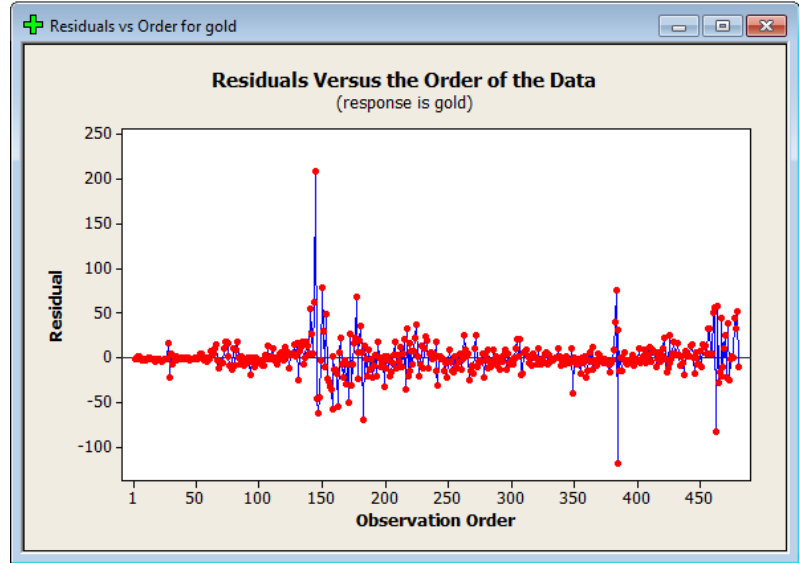

Residual versus the order of the data.

Residuals vs time data monthly price chart for gold. based on the above information, we fit the ARIMA model.

\section{ARIMA model}

So far we have $\mathrm{q}$ and $\mathrm{p}$ degrees from the ACF and PACF plot recognize that it is not necessarily a reason Just estimated. you can select the best type of trial and error. note that for the the time difference $d=1$ we take it in the ARIMA model under review: ARIMA (p, d, q) = ARIMA $(2,1,2)$ To fit this model ARIMA window will fill in the form below.

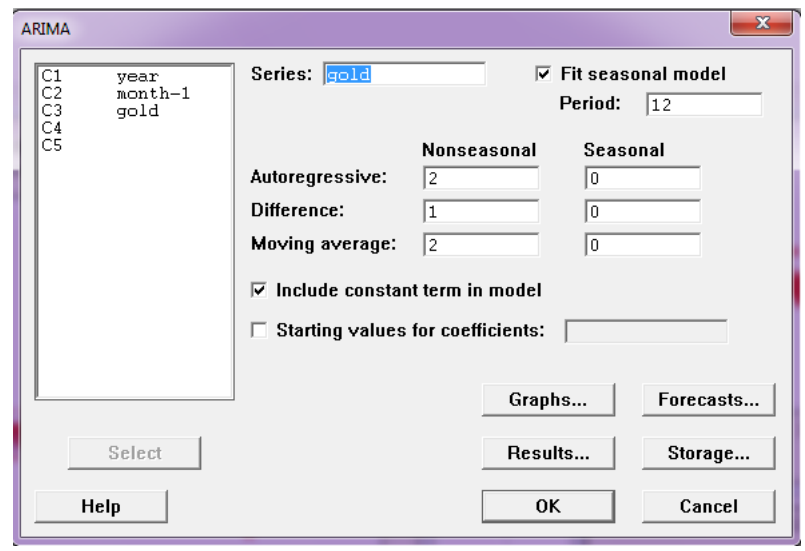

As you can see from the output port- mantoux test is as follows.

\begin{tabular}{|c|c|c|c|}
\hline Type & Coef & SE Coef & P \\
\hline AR 1 & -0.2124 & $0.5827-0.36$ & 0.716 \\
\hline AR 2 & 0.0559 & $0.3718 \quad 0.15$ & 0.881 \\
\hline MA 1 & -0.3785 & $0.5788-0.65$ & 0.513 \\
\hline MA 2 & 0.1942 & $0.4642 \quad 0.42$ & 0.676 \\
\hline Constant & 1.837 & $1.093 \quad 1.68$ & 0.093 \\
\hline \multicolumn{4}{|c|}{$\begin{array}{l}\text { Differencing: } 1 \text { regular difference } \\
\text { Number of observations: Original series } 480 \text {, after differencing } 479\end{array}$} \\
\hline \multicolumn{4}{|c|}{$\begin{array}{l}S S=193206 \quad \text { (backforecasts ex } \\
M S=408 \quad D F=474\end{array}$} \\
\hline \multicolumn{3}{|c|}{ Modified Box-Pierce (Ljung-Box) C } & hi-Square statistic \\
\hline Lag & 12 & 36 & 48 \\
\hline Chi-Square & 12.2 & 43.0 & 53.7 \\
\hline $\mathrm{DF}$ & 7 & 19 & 43 \\
\hline P-Value & 0.094 & $0.194 \quad 0.074$ & 0.128 \\
\hline
\end{tabular}


As you can see the amount of P-Value is greater than 0.05 for all the delays. also we see the P-Value for delays of $12,24,36$, and 48 more. so it can be defragmented hypothesis remains closed to admit. so it can be confirmed on the model.

\section{Conclusion}

Now, using the Box-Jencks, ARIMA modeling strategies to identify, we can make it on the Sri projected average monthly price of gold on the London market in 1968, and 2007 put. In this issue, we set the values for twelve months. we expect the average monthly price of gold. to do this, open another window and ARIMA model, ARIMA $(3,1)$ it will fit. then click on the option forecasts at the bottom of the window and the window opened at a number of 12 , we entered the lead. origin box to specify the starting point forecast. if this is something to write predictions of the end of the series will be produced. storage can be predicted values and the predictions of the store. the forecast for the next twelve months will be using this model as follows:

\begin{tabular}{rrrrr} 
& & \multicolumn{3}{c}{95 Percent } \\
Period & Forecast & Lower & Upper & Actual \\
481 & 797.478 & 757.875 & 837.080 & \\
482 & 802.641 & 741.981 & 863.302 & \\
483 & 805.868 & 733.582 & 878.154 & \\
484 & 806.476 & 723.830 & 889.121 & \\
485 & 807.873 & 715.189 & 900.557 & \\
486 & 809.755 & 708.163 & 911.347 & \\
487 & 811.360 & 701.718 & 921.003 & \\
488 & 812.889 & 695.694 & 930.084 & \\
489 & 814.495 & 690.183 & 938.808 & \\
490 & 816.108 & 685.079 & 947.138 & \\
491 & 817.701 & 680.286 & 955.116 & \\
492 & 819.295 & 675.774 & 962.817
\end{tabular}

To view the predicted values in the graph in the main, window ARIMA time series is adequate on option's graphs button and the window was opened, which is the first option time series plot (including optional forecasts) choose. and so the plot time series forecasting in the following twelve months.

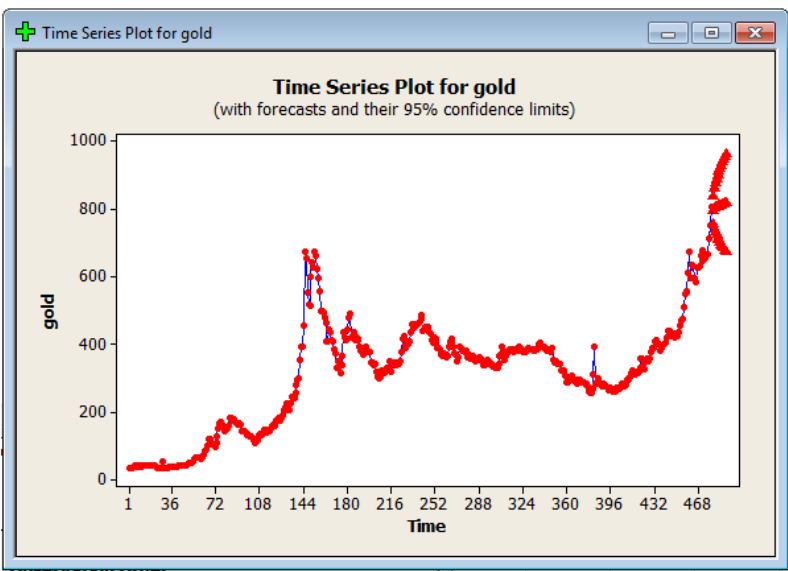

Time series plot for gold.

Series of monthly gold price forecast based on ARIMA (3, 1, and $0)$.

In the diagram above and below the center line of the predicted values and the upper limit and lower limit of the confidence interval $0.05 \mathrm{CI} 0.05$ to predict anticipated shows.

\section{References}

[1] Frankfurter George M. and G. McGoun Elton., Market Efficiency or Behavioral Finance: The Nature of the Debate, The Journal of Psy- chology and Financial Markets, Vol.1, Nos. 3 \& 4, 2000 pp. 200-210 http://dx.doi.org/10.1207/S15327760JPFM0134_5.

[2] Shiller Robert J., Tools For Financial Innovation: Neoclassical Versus Behavioral Finance, The Financial Review 41, 2006, pp.1-8. http://dx.doi.org/10.1111/j.1540-6288.2006.00129.x.

[3] Waller W.S., Auditors' Assessments of Inherent Risk and Control Risk in Field Settings, The Accounting Review, Vol. 68, No. 4, October, pp.583-803, 1993.

[4] The Commission of the European Communities, Commission Recommendation of 6 May 2003 Concerning the Definition of Micro, Small and Medium-sized Enterprises, Official Journal of the European Union L124, Vol. 46, 2003, pp. 36-41, p. 39.

[5] Jose ML, C. Lancaster, and JL Stevens, Corporate Returns and Cash ConversionCycles, Journal of Economics and Finance. 20 (1), pp. 3346, 1996. http://dx.doi.org/10.1007/BF02920497.

[6] Deloof M., Does Working Capital Management Affect Profitability of Belgian Firms? Journal of Business, Finance and Accounting, 2003, pp. 573-587. http://dx.doi.org/10.1111/1468-5957.00008.

[7] Mixtures with Discounting Learning Algorithms, Data Mining and Knowledge Discovery, Vol. 8, 2004, pp. 275-300. http://dx.doi.org/10.1023/B:DAMI.0000023676.72185.7c.

[8] Yue D., X. Wu, Y. Wang, Y. Li and C. Chu, A Review of Data Min ing-based Financial Fraud Detection Research, International Confer ence on Wireless Communications, Networking and Mobile Compu ting, 2007, pp. 5519-5522.

[9] Zhang D. and L. Zhou, Discovering Golden Nuggets: Data Mining in Financial Application, IEEE Transactions on Systems, Man and Cybernetics, Vol. 34(4), 2004, pp.513-522. http://dx.doi.org/10.1109/TSMCC.2004.829279.

[10]Zhou W., G. Kapoor, Detecting Evolutionary Financial State ment Fraud, Decision Support Systems, Vol. 50(3), 2011, pp. 570-576. http://dx.doi.org/10.1016/j.dss.2010.08.007.

[11]Brown CE, Expert Systems in Public Accounting: Current Prac tice and Future Directions, Expert Systems with Applications, 3 (1), 1991, 3-18. http://dx.doi.org/10.1016/0957-4174(91)90084-R.

[12]Connell NAD, Expert Systems in Accountancy: A Review of Some Recent Applications, Accounting and Business Research, 17 (67), 1987, 221-233. http://dx.doi.org/10.1080/00014788.1987.9729802.

[13]Frankfurter George M. and G. McGoun Elton., Market Efficien cy or Behavioral Finance: The Nature of the Debate, The Journal of Psychology and Financial Markets, Vol.1, Nos. 3 \& 4, 2000 pp. 200-210 http://dx.doi.org/10.1207/S15327760JPFM0134 5.

[14] Shiller Robert J., Tools for Financial Innovation: Neoclassical Ver sus Behavioral Finance, the Financial Review 41, 2006, pp.1-8. http://dx.doi.org/10.1111/j.1540-6288.2006.00129.x.

[15]Waller W.S., Auditors' Assessments of Inherent Risk and Con tro Risk in Field Settings, The Accounting Review, Vol. 68, No. 4, October, pp.583-803, 1993.

[16]The Commission of the European Communities, Commission Rec ommendation of 6 May 2003 Concerning the Definition of Micro, Small and Medium-sized Enterprises, Official Journal of the Euro pean Union L124, Vol. 46, 2003, pp. 36-41, p. 39.

[17]Jose ML, C. Lancaster, and JL Stevens, Corporate Returns and Cash ConversionCycles, Journal of Economics and Finance. 20 (1), pp. 33 46, 1996. http://dx.doi.org/10.1007/BF02920497.

[18]Deloof M., Does Working Capital Management Affect Profitabil ity of Belgian Firms? Journal of Business, Finance and Accounting, 2003, pp. 573-587. http://dx.doi.org/10.1111/1468-5957.00008.

[19]Mixtures with Discounting Learning Algorithms, Data Mining and Knowledge Discovery, Vol. 8, 2004, pp. 275-300. http://dx.doi.org/10.1023/B:DAMI.0000023676.72185.7c

[20] [20] Yue D., X. Wu, Y. Wang, Y. Li and C. Chu, A Review of Data Min ing-based Financial Fraud Detection Research, International Confer ence on Wireless Communications, Networking and Mobile Compu ting, 2007, pp. 5519-5522.

[21]Zhang D. and L. Zhou, Discovering Golden Nuggets: Data Min ing in Financial Application, IEEE Transactions on Systems, Man and Cy-

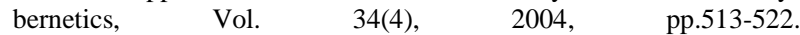
http://dx.doi.org/10.1109/TSMCC.2004.829279.

[22]Zhou W., G. Kapoor, Detecting Evolutionary Financial State ment Fraud, Decision Support Systems, Vol. 50(3), 2011, pp. 570-576 http://dx.doi.org/10.1016/j.dss.2010.08.007.

[23]Brown CE, Expert Systems in Public Accounting: Current Prac tice and Future Directions, Expert Systems with Applications, 3 (1), 1991 , 3-18. http://dx.doi.org/10.1016/0957-4174(91)90084-R.

[24]Connell NAD, Expert Systems in Accountancy: A Review of Some Recent Applications, Accounting and Business Research, 17 (67), 1987, 221-233. http://dx.doi.org/10.1080/00014788.1987.9729802. 